\title{
Breast and ovarian cell behavior in the presence of contraceptive ingredients
}

\begin{abstract}
Breast cancer is the most frequently diagnosed cancer and the second leading cause of cancer death amongst women in the United States. Breast cancer growth can be fueled by estrogen, progesterone, and growth hormones such as HER2/neu gene. The ovaries are the key source of Estrogen and Progesterone. Different studies and analysis data on over 150,000 reveal a $7 \%$ increase in breast cancer rates when women are on contraceptives. The overall purpose of this study was to evaluate the behavior of breast and ovarian cells in the presence of common contraceptive ingredients Ethinyl Estradiol (EE) and Levonorgestrel (LNG). Both cell lines were evaluated at high-dose concentrations of EE and LNG as well as serum-level concentrations comparable with those of approved contraceptives. It was hypothesized that Levonorgestrel and Ethinyl Estradiol in contraceptives could have an oncogenic effect in breast and ovarian cells. Results showed that high concentrations of EE dramatically decrease the proliferation rate of both ovarian and breast cells. On the other hand, cells treated with serum-level concentrations of EE increased proliferation in both cell lines. Breast and Ovarian cells treated with high concentrations of LNG displayed a slight/modest decrease in proliferation respectively. Ovarian cells treated with serum-level concentrations of LNG found on contraceptive users displayed an increased proliferation rate if treated individually and/or in combination with EE. Breast cells treated with serum-level concentrations of LNG did not exhibit a notable impact in proliferation, however, when LNG was combined with EE at serum-level concentrations; a decreased in proliferation was observed.
\end{abstract}

Keywords: Chinese hamster ovarian cells, human breast cells, oral contraceptives, ethinyl estradiol, breast cancer, ovarian cancer, levonorgestrel
Volume 7 Issue 2 - 2020

MedranoSusana,' Sidhu Karandeep, ' Valdivia

Ashley Lauren,' TawilBill,'2

'Department of Biotechnology and Bioinformatics, California State University, USA

${ }^{2}$ Department of Biomedical Engineering, University of California, USA

Correspondence: Bill Tawil, Department of Bioengineering, UCLA School of Engineering, 420 Westwood Plaza, Room 5121, Engineering V. P.O. Box: 951600 , Los Angeles, CA 900951600, USA, Email btawil@seas.ucla.edu

Received: February 16, 2020 | Published: April 22, 2020

\section{Abbreviations: CHO, Chinese hamster ovarian} cells;DMSO, dimethylsulfoxide;ECM, extracellular matrix;LNG, levonorgestrel,EE, ethinyl estradiol

\section{Introduction}

In this study, the impact of common contraceptive ingredients Ethinyl Estradiol (EE) and Levonorgestrel (LNG) at equivalent serumlevel concentrations comparable with those of women who were treated with contraceptives. The physiological study of the female menstrual cycle is an important avenue into learning more about the effects of different commonly prescribed female contraceptives. The cycle consists of three distinct events: the follicular phase (preovulatory), ovulation, and the luteal phase (postovulatory). The cycle is on average 20-40 days long and starts with the follicular phase where the pituitary gland releases the FSH hormone, which causes the female body to start developing immature oocytes. The first 3-7 days of the follicular phase is known as menstruation and is when the body is expelling endometrial tissue and other remnants of the previous menstrual cycle. The follicular phase lasts around 14 days and causes the ovaries to produce the hormone oestrogen. The follicular phase ends when a surge of LH is produced from the pituitary gland due to the rise of oestrogen from the ovaries. ${ }^{1-18}$ The LH surge triggers ovulation and release of a mature egg cell into the fallopian tubes. The next phase is known as the luteal phase and is when the unfertilized egg and corpus luteum influence the production of the hormone progesterone. The hormone progesterone is important because it helps to maintain and thicken the uterine lining. The cycle will start all over again if the individual egg does not get fertilized. ${ }^{19}$
The female menstrual cycle can be manipulated and changed due to natural and artificial methods. The hormone prolactin is produced during pregnancy and inhibits ovulation by encouraging the production of milk. The hormone continues to prevent ovulation as long as the individual continues to breastfeed and stops preventing ovulation 6-8 weeks post breastfeeding. A commonly used method of preventing the menstrual cycle is the use of hormonal contraceptives, which are administered orally, intramuscularly, transdermally, subcutaneously, and intravaginally. ${ }^{19}$

Oral contraceptives were introduced to the market in the $1960 \mathrm{~s}$ containing over $35 \mu \mathrm{g}$ of estrogens and over $2.5 \mathrm{mg}$ of progestin, as each new generation was introduced, the concentrations of each ingredient have been reduced. ${ }^{20-34}$ Contraceptives work by synthetically providing estrogen and progesterone, which prevents ovulation, cervical mucus discharge, and thickening of the uterine wall lining. Contraceptives suppress levels of pituitary hormones LH and FSH while maintaining constant levels of estrogen and progesterone. ${ }^{35,36}$ Individuals suffering from certain medical conditions such as dysmenorrhea, menorrhagia, and premenstrual dysphonic disorder can all receive benefits from using contraceptives. ${ }^{19}$

The use of birth control contraceptives is believed to encourage certain diseases while lowering the chances of others. According to the American Cancer Society (ACS), the risk of certain cancers such as endometrial, ovarian, and colon cancers is reduced due to the use of hormone-altering birth control contraceptives while the risk is increased for breast and cervical cancers. ${ }^{20}$ The specific reasons for decreasing endometrial, and colon cancer rates are unclear but researchers believe hormonal contraceptives suppress endometrial 
cell proliferation and decrease the amount of bile acids in the blood, therefore, reducing colon cancer and endometrial cancer rates. ${ }^{22}$ Other long-term risk factors include increased chances of inducing cardiovascular incidents such as stroke, venous thromboembolism, and myocardial infarctions..$^{21}$ Other hormonal and nonhormonal longterm contraceptive options exist such as hormonal patches, vaginal rings, and contraceptive shots.

The female breast is the female organ with the specialized function of milk production for lactation, sitting atop the pectoralis muscle. ${ }^{2}$ The female breast consists of stromal (connective) tissue, adipose tissue, lobes, lobules, milk ducts, ligaments, fibrous connective tissue, nerves, lymph vessels, lymph nodes, and blood vessels. ${ }^{1}$ Breast cancer growth can be fueled by estrogen, progesterone, and growth hormones such as HER2/neu gene. In this study we selected non-cancerous human breast cells to evaluate their behavior in the presence of contraceptive hormones. The ovaries are the female reproductive glands and are the key source of the female hormones estrogen and progesterone. There are three types of cells in the ovaries, Surface Epithelium, which cover the outer lining of the ovaries, Germ Cells, which are fated to form eggs, and Stroma Cells, which release hormones and connect structures in the ovaries. ${ }^{9}$ Chinese hamster ovary cells $(\mathrm{CHO})$ are an established line in the production of pharmaceuticals and offer a stable vehicle of study. ${ }^{8}$ In this study, the Chinese Hamster Ovarian $(\mathrm{CHO})$ cells were selected to evaluate their behavior in the presence of contraceptive hormones.

Oestrogen is also known as Estrogen, it is a female sex hormone which levels vary depending on the menstrual cycle and stage of life; the highest levels are found in the middle of the cycle and the lowest during menstruation. Estrogens feed the proliferation of the endometrium after the menstrual cycle and induce the expression of the progesterone receptor. Norethindrone, levonorgestrel, norgestrel, gestodene, and norprogestin medroxyprogesterone are progestins, or synthetic forms of progesterone, a female hormone that regulates ovulation and menstruation. Progesterone is involved in proliferation, differentiation, and maintenance of the endometrial epithelium and stroma before implantation. Progestins are agonist to the progesterone receptor, which means they bind chemically with high affinity to the receptor and trigger signaling. ${ }^{33}$

In this study, it was hypothesized that some contraceptive ingredients such as Levonorgestrel and Ethinyl Estradiol might impact the adhesion and proliferation of human breast cells and Chinese hamster ovarian cells $(\mathrm{CHO})$. In the following experiments, the behavior of each cell line in 2D culture as well as the effect of both contraceptive ingredients on breast and ovarian cells was evaluated. First, the optimal cell densities and substrates were identified for 2D culture of each cell line. Second, the behavior of each cell line was studied at high-dose concentrations of Ethinyl Estradiol (EE) and Levonorgestrel (LNG) separately. Last, the behavior of each cell line was studied at equivalent serum-level concentrations comparable with those of women who were treated with contraceptives, both separately and in combination.

The study was designed to be comparable with blood level concentrations of EE and LNG found on contraceptive users. During a Phase 1 clinical study for Twirla ${ }^{\circledR}$ (AG200-15), a transdermal low-dose contraceptive delivery system, it was found that the mean ( \pm standard deviation) maximum serum blood concentration (Cmax) of Levonorgestrel had increased from $1010 \pm 484 \mathrm{pg} / \mathrm{mL}$ at the start of the first cycle to $2840+1170 \mathrm{pg} / \mathrm{mL}$ at the end of the second cycle.
Ethinyl Estradiol had increased from $38.9 \pm 14.8 \mathrm{pg} / \mathrm{mL}$ at the start of the first cycle to $57.8 \pm 18.2 \mathrm{pg} / \mathrm{mL}$ at the end of the second consecutive cycle. The accumulation of both hormones in blood plasma was demonstrated as the overall drug exposure was measured utilizing the Area Under the Curve $\left(\mathrm{AUC}_{0-16 \mathrm{~B}} \mathrm{~h}\right)$, for $\mathrm{LNG}$ it increased to $378 \pm 166 \mathrm{ng}$ $\mathrm{h} / \mathrm{mL}$ and for EE it increased to $7.12+2.61 \mathrm{ng} \mathrm{h} / \mathrm{mL}$ by the end of the second cycle. ${ }^{27}$ Another study for the first transdermal contraceptive delivery system (ORTHO EVRA) reported after two cycles of the patch the $\mathrm{C}_{\max }$ of Norgestrel, a synonym of Levonorgestrel to be at $2.62 \mathrm{ng} / \mathrm{mL}$ and Ethinyl Estradiol at $102 \mathrm{pg} / \mathrm{mL}$. The accumulation of both hormones was also shown as also measured utilizing $\mathrm{AUC}_{0-168} \mathrm{~h}$, where EE increased to $13,504 \mathrm{pg} * \mathrm{~h} / \mathrm{mL}$ and Norgestrel to $370 \mathrm{ng} * \mathrm{~h} /$ $\mathrm{mL}$. When compared to the oral contraceptive (Cilest), the $\mathrm{C}_{\max }$ was lower but the overall exposure (AUC) by the end of the first cycle was lower in oral contraceptives (Figure 1). ${ }^{26}$

\section{Initial Adhesion of Ovarian Cells on High Concentrations of Ethinyl Estradiol}

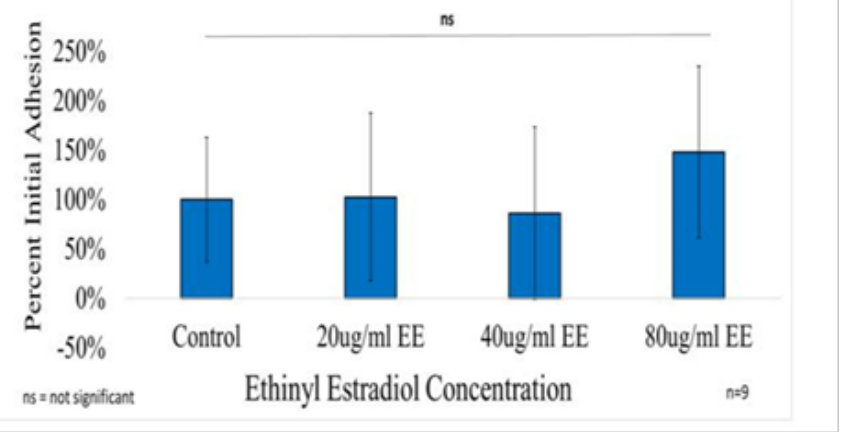

Figure I (A) Initial Adhesion of Ovarian Cells with Ethinyl Estradiol on I0 $\mu g$ / $\mathrm{ml}$ Collagen Matrices: Initial adhesion of ovarian cells did not have a significant impact with the addition of Ethinyl Estradiol, no apparent trend was observed as the concentration of EE was increased.

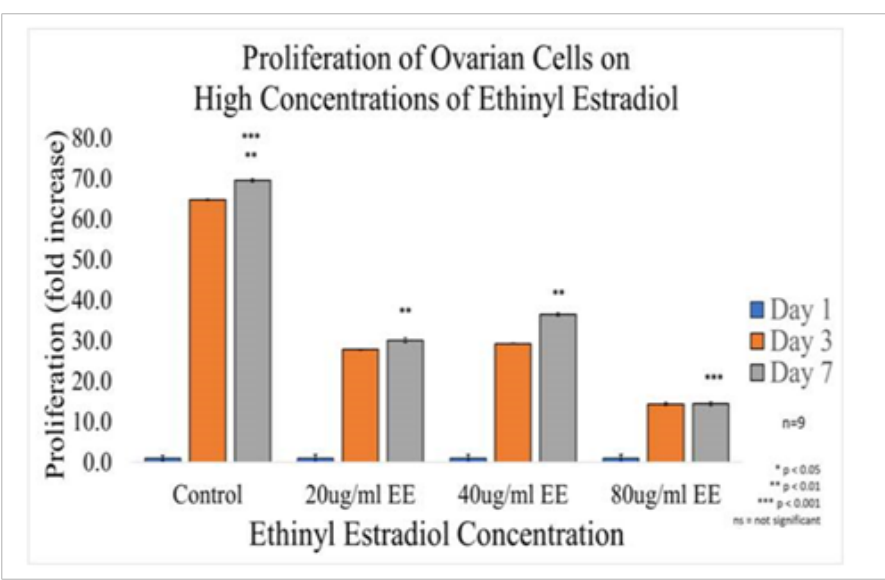

Figure (IB) Proliferation of Ovarian Cells with Ethinyl Estradiol on I0 $\mathrm{\mu g} /$ $\mathrm{ml}$ Collagen Matrices: Proliferation of ovarian cells decreased dramatically with the addition of Ethinyl Estradiol, a statistical significanceof at least $p<0.0$ I was observed on Day 7.

\section{Materials and methods}

Cell Culture: Chinese Hamster Ovary Cells (CHO) and Human Breast Cells (Hs $578 \mathrm{Bst}$ ) were cultured in a $75 \mathrm{~mL}$ boat flask (Thermo Scientific $^{\mathrm{TM}}$, Waltham, MA, USA) utilizing their respective media 
and incubated (Thermo Scientific ${ }^{\mathrm{TM}}$, Waltham, MA, USA) at $35^{\circ} \mathrm{C}$ with $5 \% \mathrm{CO}_{2}$. Cell Count: Cells were confirmed healthy under the phase- contrast microscope CKX41 (Olympus ${ }^{\circledR}$, Shinjuku, Tokyo, Japan) before treatment, which included removal of storage media and double wash with $5 \mathrm{~mL}$ of sterile phosphate buffer saline each time (PBS) (GE Healthcare, Chicago, IL, USA) before trypsinazation. Trypsinization of cells was performed by the addition of $5 \mathrm{~mL}$ of trypsin (GE Healthcare, Chicago, IL, USA) followed by an incubation time of 7 minutes for ovarian cells and 11 minutes for breast cells at room temperature. After confirming cell dissociation under the phasecontrast microscope, $5 \mathrm{~mL}$ of media was added to stop trypsinization, the solution was then transferred to a $15 \mathrm{ml}$ conical tube (Fisherbrand, Waltham, MA, USA) for centrifugation(Figure 2). A cell pellet was obtained by centrifuging Eppendorf AG, Hamburg, Germany) the trypsinized cells for five minutes at 200G. The supernatant was then removed and the cells were later re-suspended in $1 \mathrm{~mL}$ of their respective media and cell density was measured by adding $20 \mu \mathrm{L}$ of the cell solution to a cellometer cell counting chamber (Nexcelom Bioscience, Lawrence, MA, USA) which was processed in the Nexcelom Cellometer Auto T4 (Nexcelom Bioscience, Lawrence, MA, USA) to obtain an average cell concentration(Figure 3).

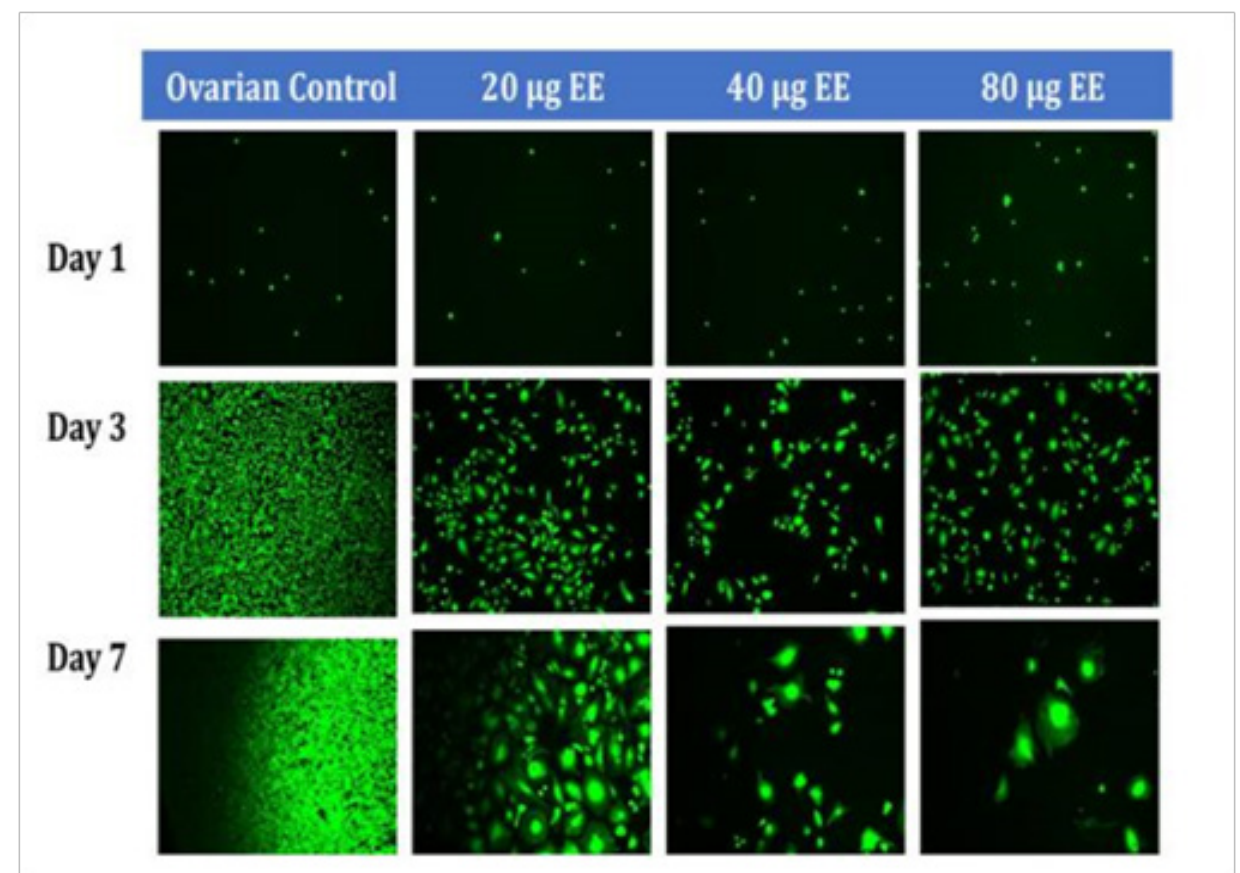

Figure (IC) Initial Adhesion and Proliferation of Ovarian Cells with Ethinyl Estradiol on 10 $\mathrm{\mu g} / \mathrm{ml}$ Collagen Matrices: The cells appeared round after I-hour incubation, slightly spindle as they proliferated. Cell morphology was altered from spindle to circular when exposed to Ethinyl Estradiol. Ovarian cells were noticeably larger in size and had lost adhesion to neighboring cells when exposed to EE.

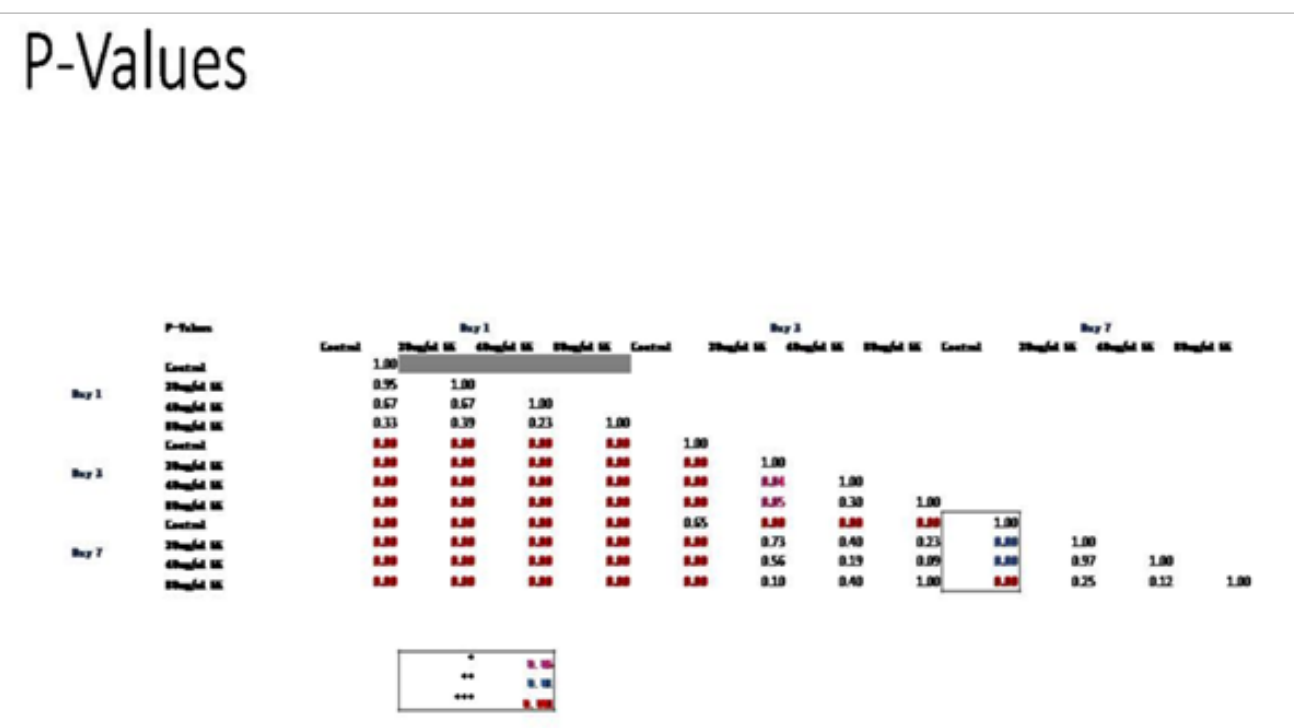

Figure (ID) P-Values of Ovarian Cells with Ethinyl Estradiol on I0 $\mathrm{\mu g} / \mathrm{ml}$ Collagen Matrices: P-Value table indicating significance of experiment results 


\section{Initial Adhesion of Ovarian Cells on High Concentrations of Levonorgestrel}

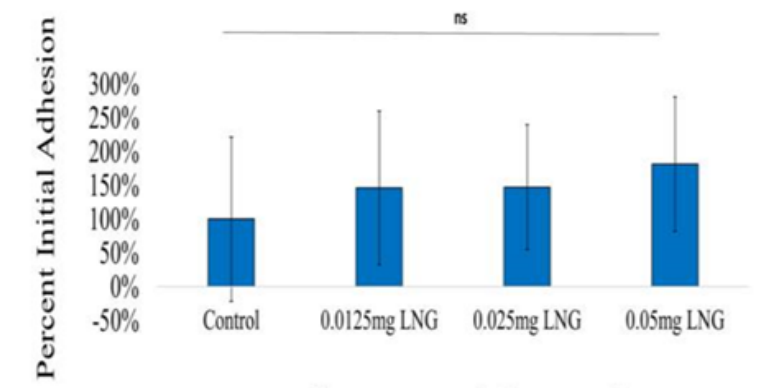

ns = not significant analytical standard (Sigma-Aldrich ${ }^{\circledR}$, St. Louis, MO, USA) in 1 $\mathrm{mL}$ of ethanol (Sigma-Aldrich ${ }^{\circledR}$, St. Louis, MO, USA) and filtered through Nalgene ${ }^{\mathrm{TM}} 25 \mathrm{~mm}$ Syringe Filters (Thermo Scientific ${ }^{\mathrm{TM}}$, Waltham, MA, USA). Approved concentrations of levonorgestrel were prepared by serial dilution method. High concentrations $(0.0125$ $\mathrm{mg} / \mathrm{mL}, 0.025 \mathrm{mg} / \mathrm{mL}$, and $0.05 \mathrm{mg} / \mathrm{mL}$ ) twenty, ten, and five times lower in comparison to the available concentrations of approved oral contraceptives. The lowest concentration of $\mathrm{LNG}$ was prepared at $1.52 \mathrm{ng} / \mathrm{mL}$, which is half the equivalent blood level concentrations of LNG found in hormone contraceptive users, ${ }^{26,27}$ it was used alone and in combination with Ethinyl Estradiol.

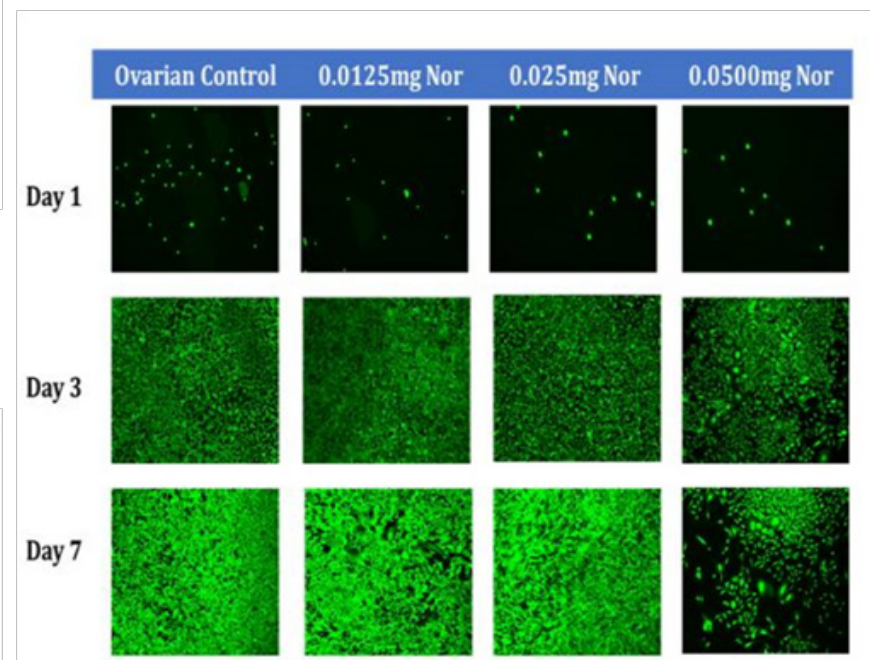

Figure 2 (C) Initial Adhesion and Proliferation of Ovarian Cells with Levonorgestrel on $10 \mu \mathrm{g} / \mathrm{ml}$ Collagen Matrices:The cells appeared round after I-hour incubation, slightly spindle as they proliferated. Cell morphology was altered and became slightly more elongated when exposed to the highest concentration of Levonorgestrel. Ovarian cells were noticeably larger in size and started to lack adhesion to their neighboring cells when exposed to the highest concentration of LNG by Day 7 .

2D cell proliferation assay: Three 24-well plates (Corning Incorporated, Corning, NY, USA) were coated using collagen $(10 \mu \mathrm{g} /$ $\mathrm{mL}$ ) as it was previously identified by our team to be the best substrate for both human breast cells and Chinese hamster ovarian cells. Cells were then seeded on 24-well plates with their respective substrates based on the approved experimental design. Cells were treated with different concentrations of levonorgestrel and Ethinyl estradiol dissolved in ethanol. Initial adhesion of the cells was examined on Day 0 after 1 hour of incubation. Proliferation was examined at days 3 and 7 (Figure 4).

Tray processing: After incubation, a Calcein-AM treatment was performed followed by a 20-minute incubation in the dark.

Quantitative data collection: Analysis in the Filtermax F5 MultiMode microplate reader was done to determine the number of live cells present in each well.

Imaging: Fluorescent images were then obtained using an Olympus IX71 inverted microscope.

\section{Statistical analysis}

Microsoft Excel was used for the statistical analysis of data, which is being presented with the mean standard deviation (SD). A

Levonorgestrel stock solutions: Levonorgestrel stock solution were prepared by dissolving $3.3 \mathrm{mg}$ of $\mathrm{D}(-)$-Levonorgestrel 
paired t-test (two-sample assuming unequal variances) was utilized to determine the significance of observed differences. A p-value of
$<0.05$ is considered statistically significant, statistical significance was assigned to $* \mathrm{p}<0.05, * * \mathrm{p}<0.01$, and $* * * \mathrm{p}<0.001$ (Figure 5).

\section{P-Values}
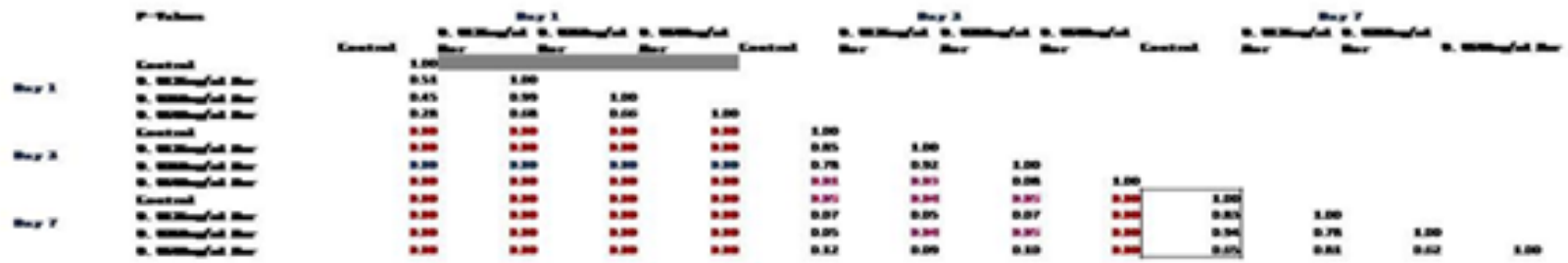

Figure 2 (D) P-Values of Ovarian Cells with Levonorgestrel on I0 $\mathrm{\mu g} / \mathrm{ml}$ Collagen Matrices:P-Value table indicating significance of experiment results.

Initial Adhesion of Ovarian Cells on Birth Control Ingredients at Serum Level Ingredients

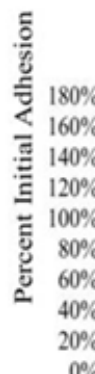

ms not ientitant
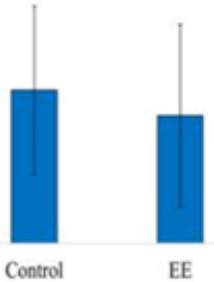

Birth Control Ingredients

Figure 3 (A) Initial Adhesion of Ovarian Cells with Equivalent Blood Level Concentrations of Birth Control Ingredients on $10 \mu \mathrm{g} / \mathrm{ml}$ Collagen Matrices: Initial adhesion of ovarian cells did not have a significant impact with the addition of birth control ingredients whether they were added individually or as a mixture, a decreasing adhesion rate trend was observed with the introduction of the ingredients.

\section{Results}

\section{Ovarian cells}

\section{The effect of collagen and fibronectin matrix on ovarian cells}

Various concentrations of collagen and fibronectin matrixes were examined to determine the best substrate for initial cell adhesion and proliferation. In general, fibronectin was observed to be the best for

rapid $\mathrm{CHO}$ cell adhesion; the concentration did not seem to impact the rate at which the cells adhered to the fibronectin matrix. On the contrary, collagen matrices appeared to be best at increasing the rate of proliferation, especially at higher concentrations of collagen. For this study, $10 \mu \mathrm{g} / \mathrm{mL}$ Collagen substrate was identified as the preferred matrix for all proliferation assays.

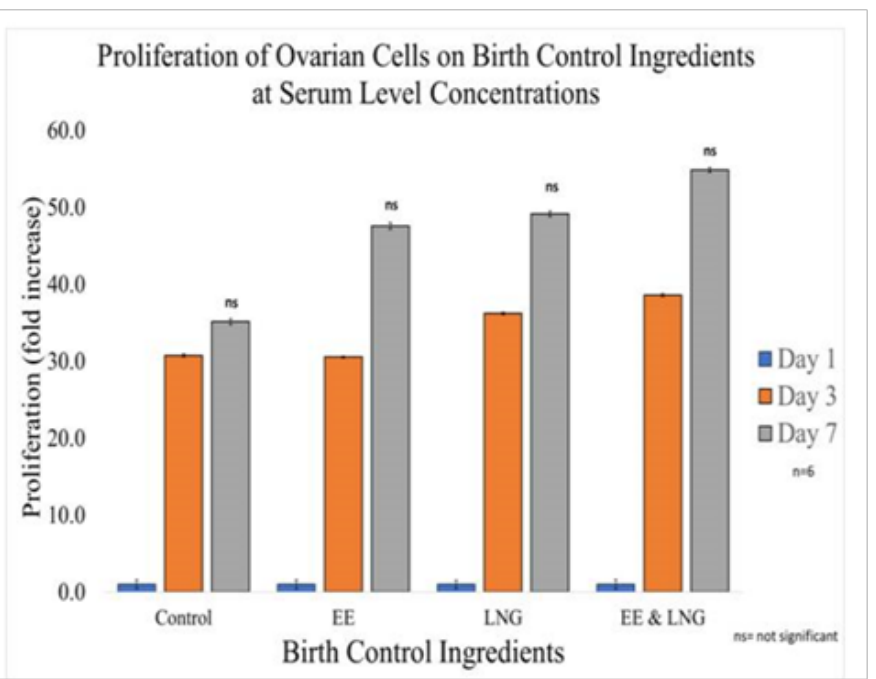

Figure 3 (B) Proliferation of Ovarian Cells with Equivalent Blood Level Concentrations of Birth Control Ingredients on $10 \mu \mathrm{g} / \mathrm{ml}$ Collagen Matrices:Proliferation of ovarian cells increased with the addition of birth control ingredients whether they were added individually or as a mixture, no statistical significance was observed on Day 7.

Ovarian Cell Adhesion and Proliferation in 2D Culture. Initial adhesion of $\mathrm{CHO}$ cells was calculated using data from a microplate reader, it was observed to increase proportionally as the concentration of cells increased by 10,000 cells, up to 40,000 cells. However, 
when the density of cells was increased to 50,000, the adhesion fell dramatically. Proliferations of $\mathrm{CHO}$ cells were only observed to increase at 10,000 cells per well on Day 3 and Day 7. A reduction in cells was observed on Day 3 for densities of 20,000 and higher. However, a slight increase was observed at Day 7 for 20,000, 30,000 , and 40,000; but it continued to decline at 50,000 cells. The morphology of the cells did not change much with time, they appeared as single spheres on Day 1 and rounded on Day 3, direct interfacial contact along membranes was visible by Day 7 . The experiments at high concentrations of EE were performed at 10,000 cell density, however, it was decreased to 5,000 cells per well for the remaining experiments of the study to be consistent with the number of breast cells being used for the parallel experiments(Figure 6).

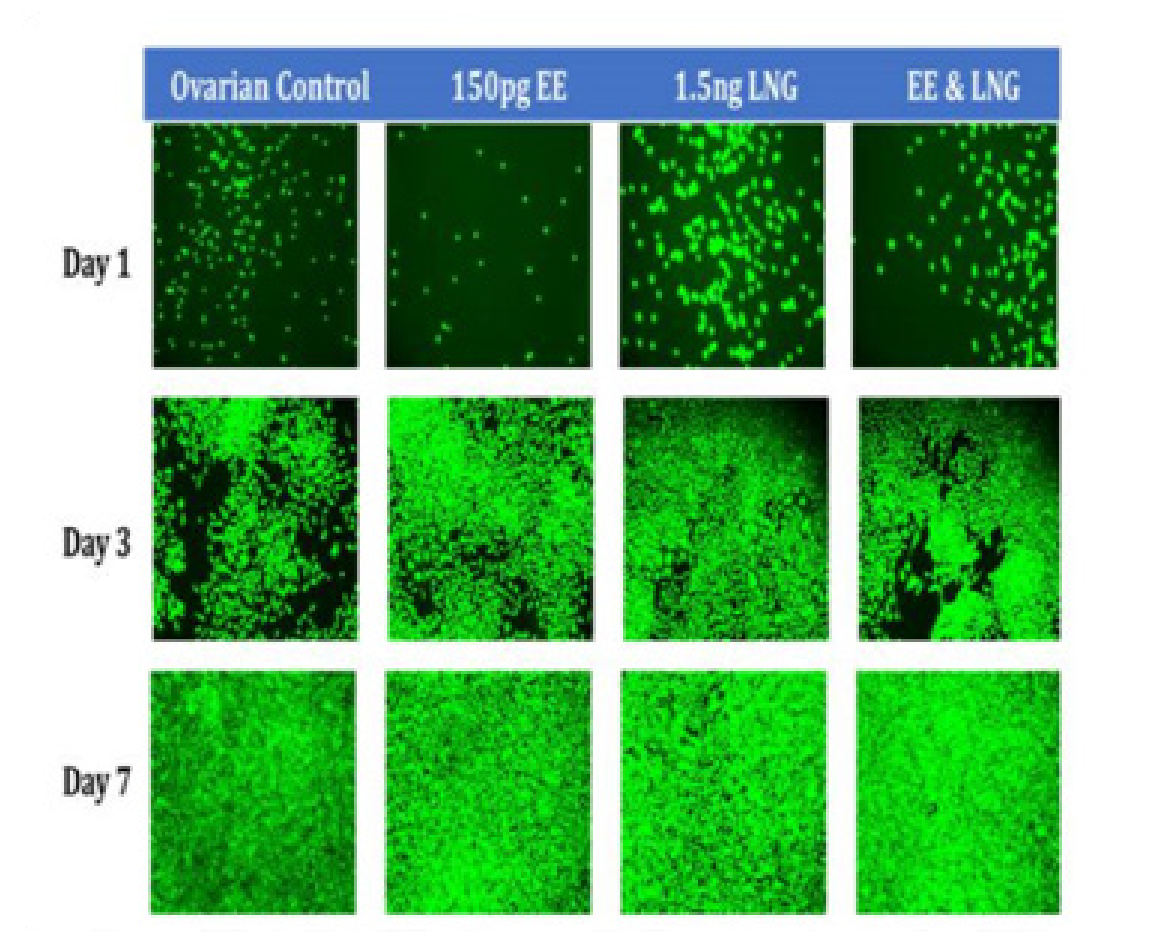

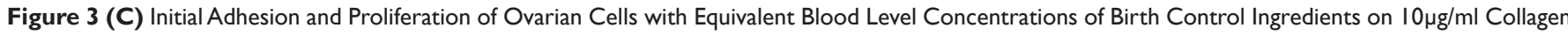
Matrices:The cells appeared round after I hour incubation, slightly spindle as they proliferated. Cell morphology was not visibly altered when exposed to equivalent blood level concentrations of birth control ingredients whether individually or in combination. A few ovarian cells were visibly larger in size on Day 3, when exposed individually to EE and LNG.Most cells appeared to have a polygonal shape by Day 3 when exposed to a combination of EE and LNG.

\section{P-Values- $\mathrm{CHO}$ combo}

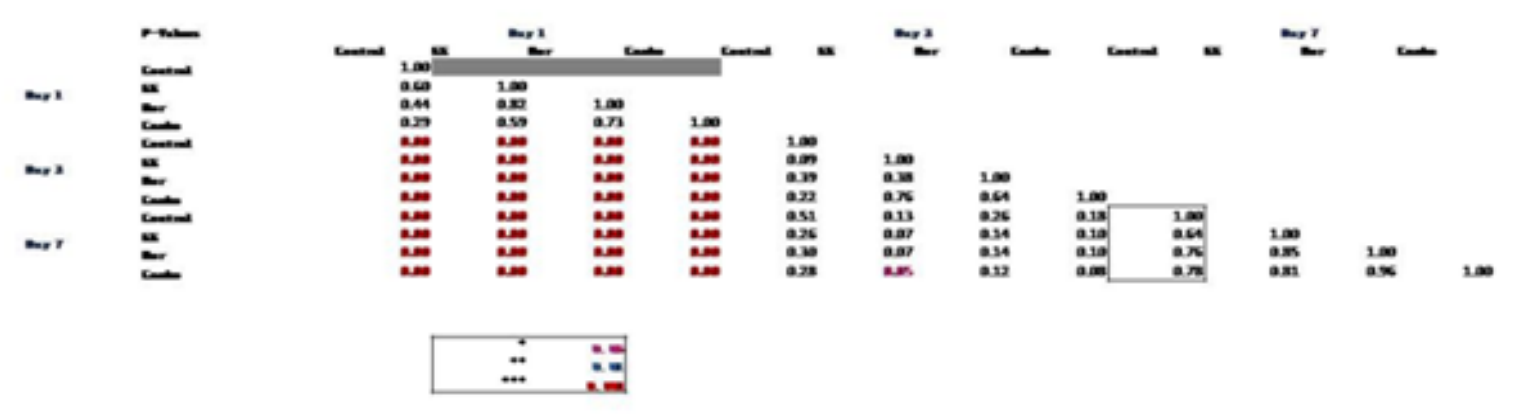

Figure 3 (D) P-Values of Ovarian Cells with Equivalent Blood Level Concentrations of Birth Control Ingredients on I0 $\mu$ g/ml Collagen Matrices: P-Value table indicating significance of experiment results. 


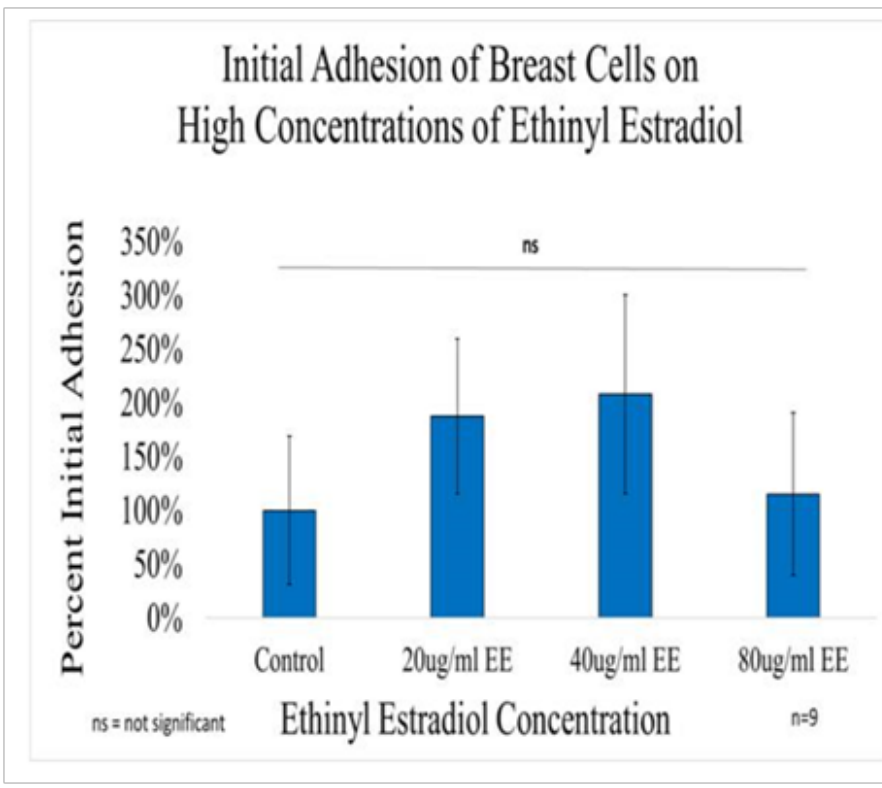

Figure 4 (A) Initial Adhesion of Breast Cells with Ethinyl Estradiol on I0 $\mathrm{\mu g} /$ $\mathrm{ml}$ Collagen Matrices: Initial adhesion of breast cells did not have a significant impact with the addition of Ethinyl Estradiol, adhesion rate was similar to the control at $80 \mu \mathrm{g} / \mathrm{ml}$ but increased at $20 \mu \mathrm{g} / \mathrm{ml}$ and $40 \mu \mathrm{g} / \mathrm{ml}$.

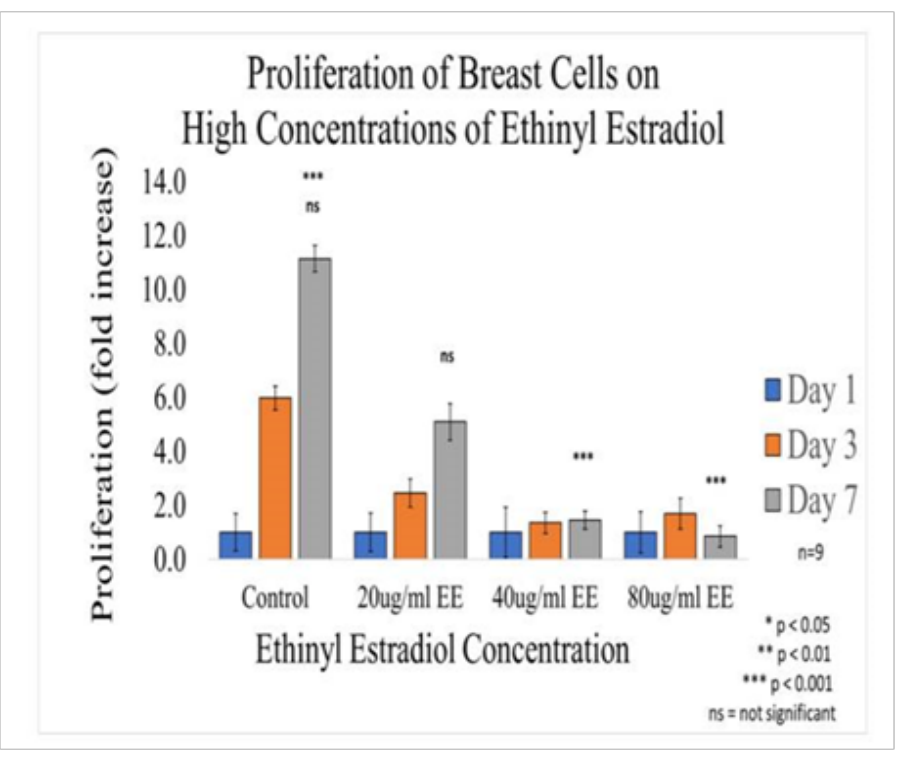

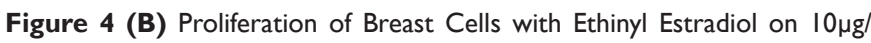
$\mathrm{ml}$ Collagen Matrices:Proliferation of breast cells decreased dramatically with the addition of Ethinyl Estradiol, a statistical significance of at $\mathrm{p}<0.001$ was observed on Day 7 at the highest concentrations.

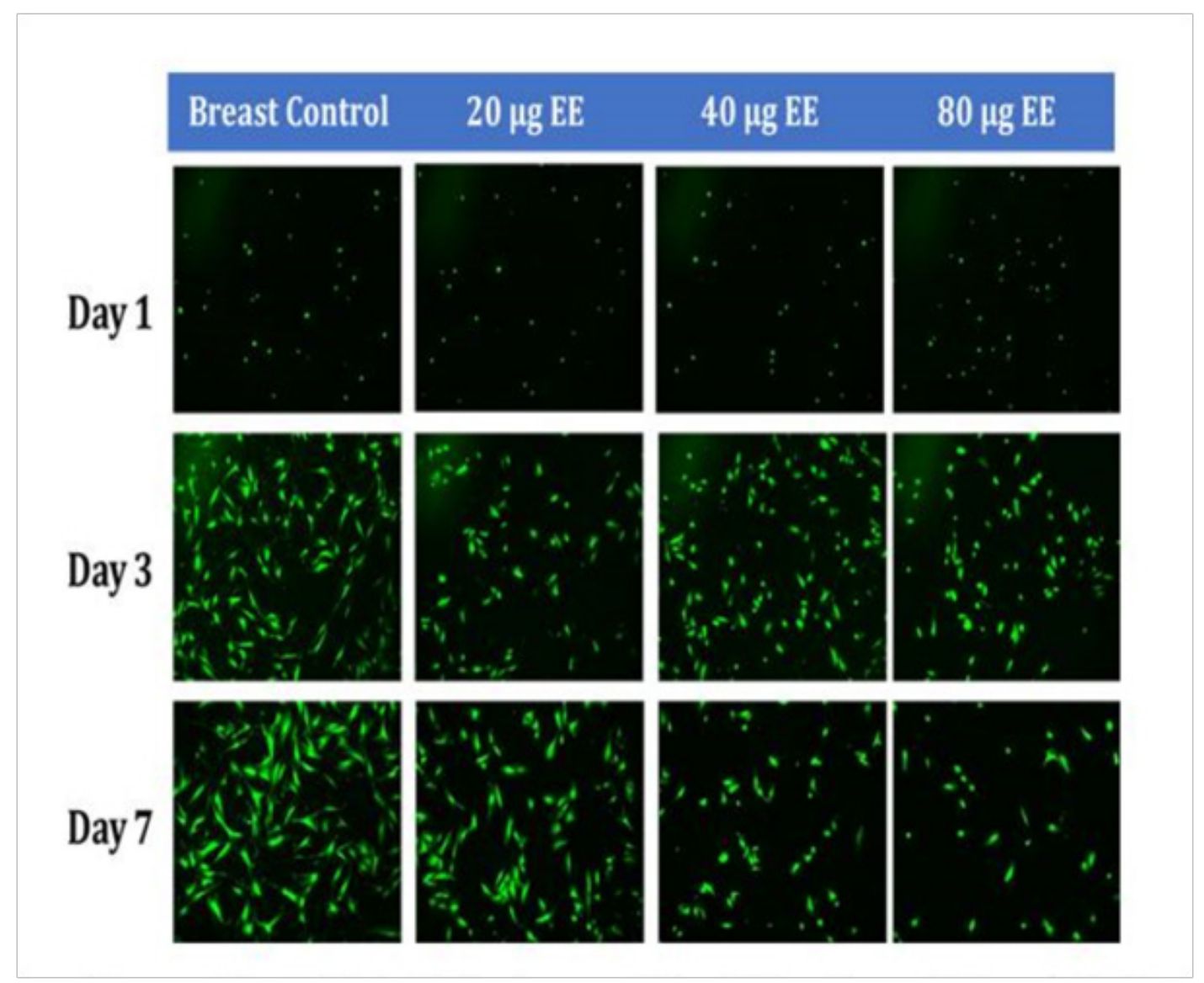

Figure 4 (C) Initial Adhesion and Proliferation of Breast Cells with Ethinyl Estradiol on 10 $\mu \mathrm{g} / \mathrm{ml}$ Collagen Matrices:The cells appeared round after I-hour incubation and consistently elongated as they proliferated. Cell morphology was altered from elongated to spindle like when exposed to Ethinyl Estradiol. Breast cells were noticeably smaller in size and polygonal in shape, the loss of adhesion to neighboring cells was evident when exposed to EE. 


\section{P-Values}

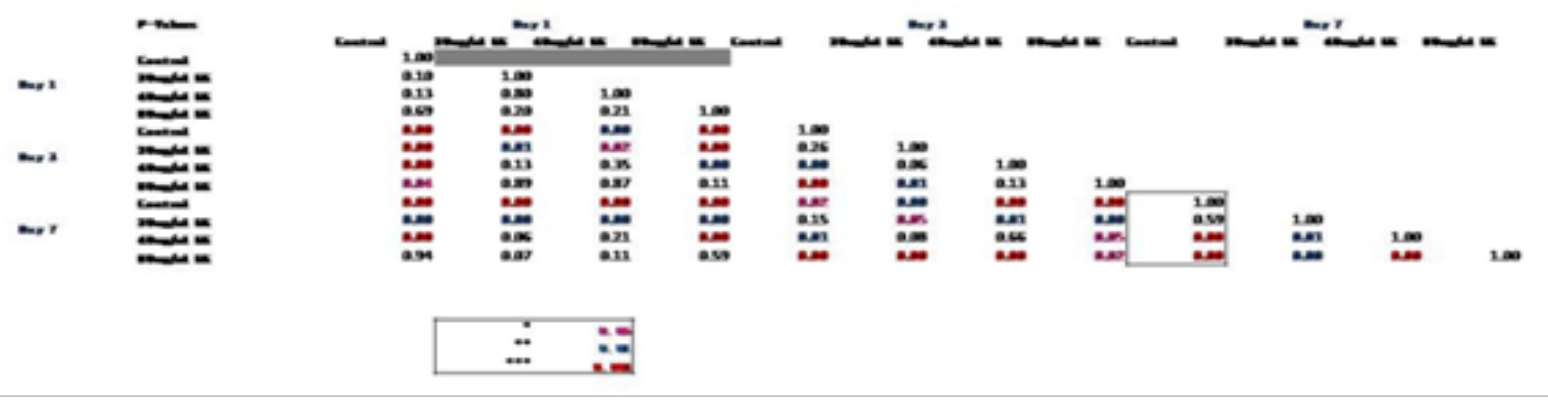

Figure 4 (D )P-Values of Breast Cells with Ethinyl Estradiol on I0 $\mathrm{\mu g} / \mathrm{ml}$ Collagen Matrices: P-Value table indicating significance of experiment results.

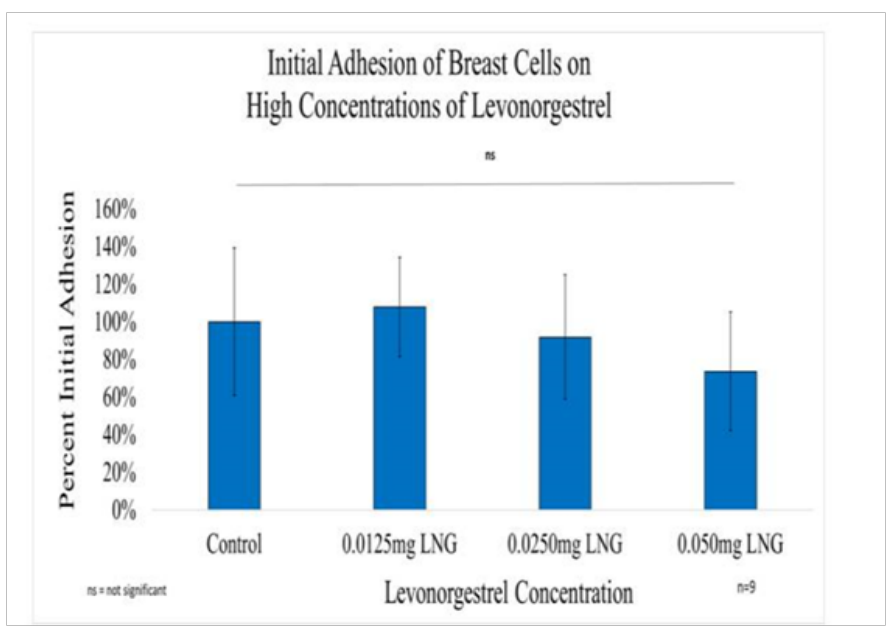

Figure 5 (A) Initial Adhesion of Breast Cells with LNG on $10 \mu g / \mathrm{ml}$ Collagen Matrices: Initial adhesion of breast cells did not have a significant impact with the addition of Levonorgestrel, a slight decrease in the adhesion rate at the highest concentration of LNG was observed.

Effect of high concentrations ethinyl estradiol in ovarian cell adhesion and proliferation in $2 \mathrm{D}$ culture

Initial adhesion of $\mathrm{CHO}$ Cells decreased $37 \%$ with the addition of $20 \mu \mathrm{g} / \mathrm{ml}$ and $74 \%$ with the addition of $40 \mu \mathrm{g} / \mathrm{ml}$ of ethinyl estradiol (EE), interestingly it increased by $26 \%$ with the addition $80 \mu \mathrm{g} / \mathrm{ml}$ of Ethinyl estradiol. However, there was no statistical significance in the results. Proliferation, on the other hand, displayed a statistical significance of at least $p<0.01$ when comparing the control to each condition of ethinyl estradiol (EE). The proliferation of CHO cells by Day 7 decreased dramatically, cells containing $20 \mu \mathrm{g} / \mathrm{ml}$ EE had a reduction of $57 \%$ in proliferation, cells containing $40 \mu \mathrm{g} / \mathrm{ml}$ decreased by $48 \%$, whereas proliferation for cells with $80 \mu \mathrm{g} / \mathrm{ml}$ decreased by $79 \%$ when compared to the control. The morphology of the cells was visibly altered by Day 3, the cells started to lose their roundness and became a bit elongated. By Day 7 the morphological changes were even more visible and seemed extremely larger and more intense at the center.

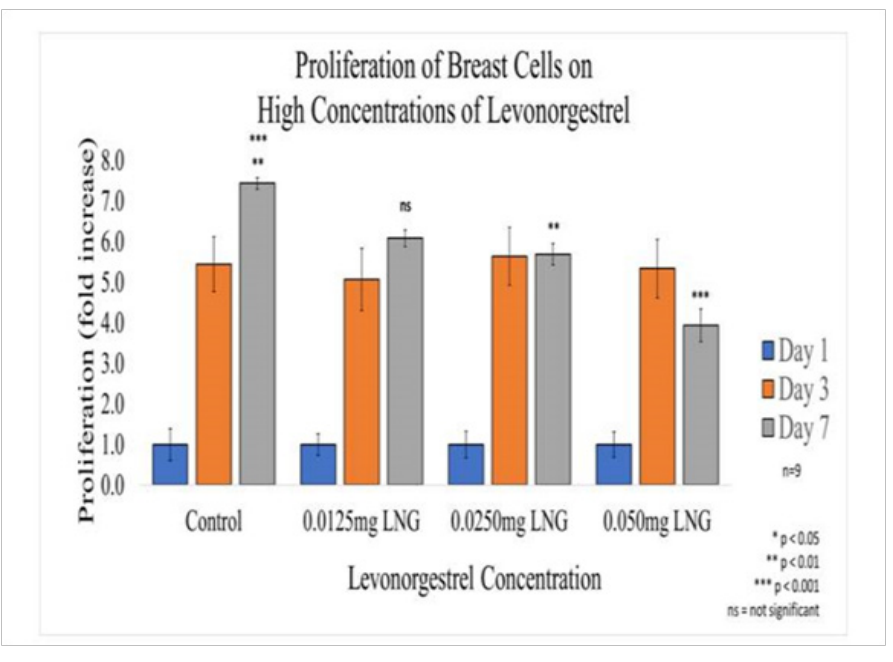

Figure 5 (B) Proliferation of Breast Cells with Levonorgestrel on I0 $\mathrm{\mu g} /$ $\mathrm{ml}$ Collagen Matrices: Proliferation of breast cells decreased with the addition of Levonorgestrel, a statistical significance of at least $p<0.0$ l for the highest concentrations was observed on Day 7.

Effect of high concentrations levonorgestrel in ovarian cell adhesion and proliferation in $2 \mathrm{D}$ culture

In general, the initial adhesion of ovarian $(\mathrm{CHO})$ cells did not have a significant impact on the addition of Levonorgestrel. Proliferation did not imply statistical significance decreasing by $50 \%$ with the addition of $0.05 \mathrm{mg} / \mathrm{ml} \mathrm{LNG}$, by $31 \%$ with the addition of $0.025 \mathrm{mg} /$ $\mathrm{ml} \mathrm{LNG}$, and by $35 \%$ with the addition of $0.0125 \mathrm{mg} / \mathrm{ml} \mathrm{LNG}$. The morphology of the ovarian cells was visibly altered by Day 3 at the highest concentration of $0.05 \mathrm{mg} / \mathrm{ml} \mathrm{LNG}$, the cells started to lose their roundness and became a bit elongated and much larger. By Day 7 the morphological changes were even more visible and seemed notably larger. 


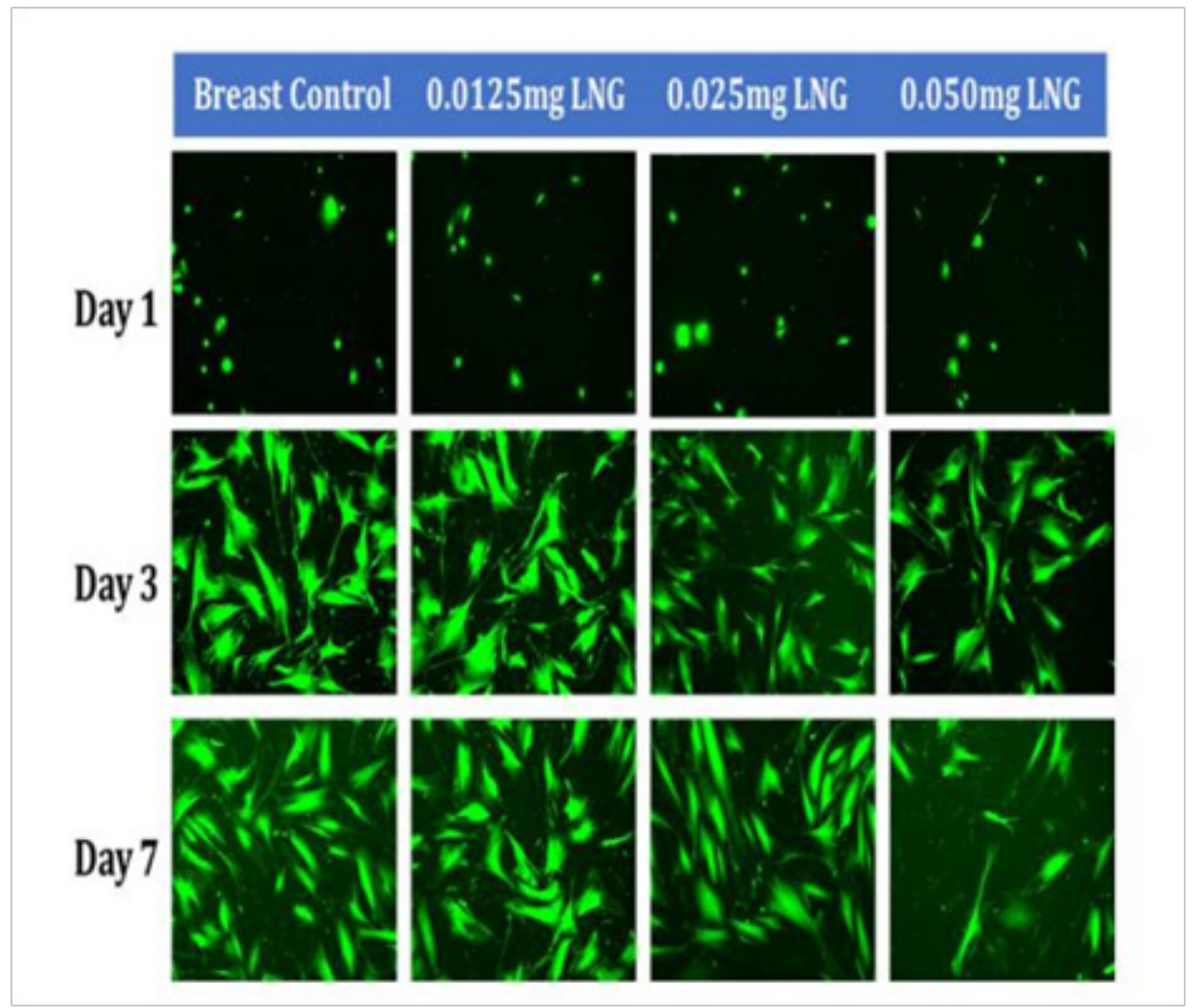

Figure 5 (C) Initial Adhesion and Proliferation of Breast Cells with Levonorgestrel on 10 $\mathrm{\mu g} / \mathrm{ml}$ Collagen Matrices: The cells appeared round after I-hour incubation and consistently elongated as they proliferated. Cell morphology was slightly altered to a polygonal shape when exposed to Levonorgestrel, a loss of adhesion to neighboring cells was prominent at the highest concentration of LNG.

\section{P-Values Breast Norgestrel}

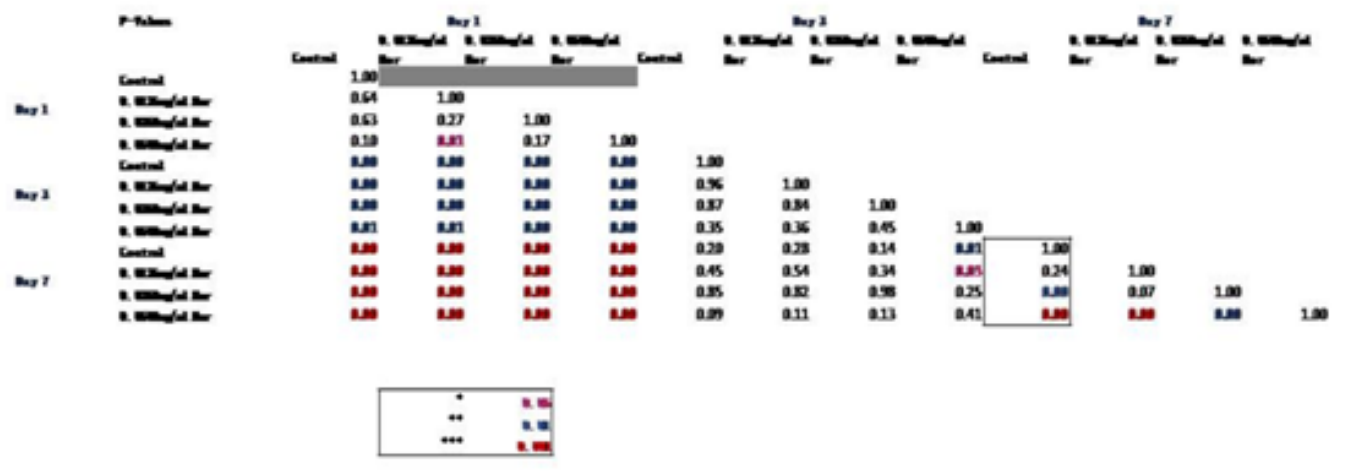

Figure 5 (D) P-Values of Breast Cells with Levonorgestrel on 10 $\mathrm{\mu g} / \mathrm{ml}$ Collagen Matrices: P-Value table indicating significance of experiment results. 


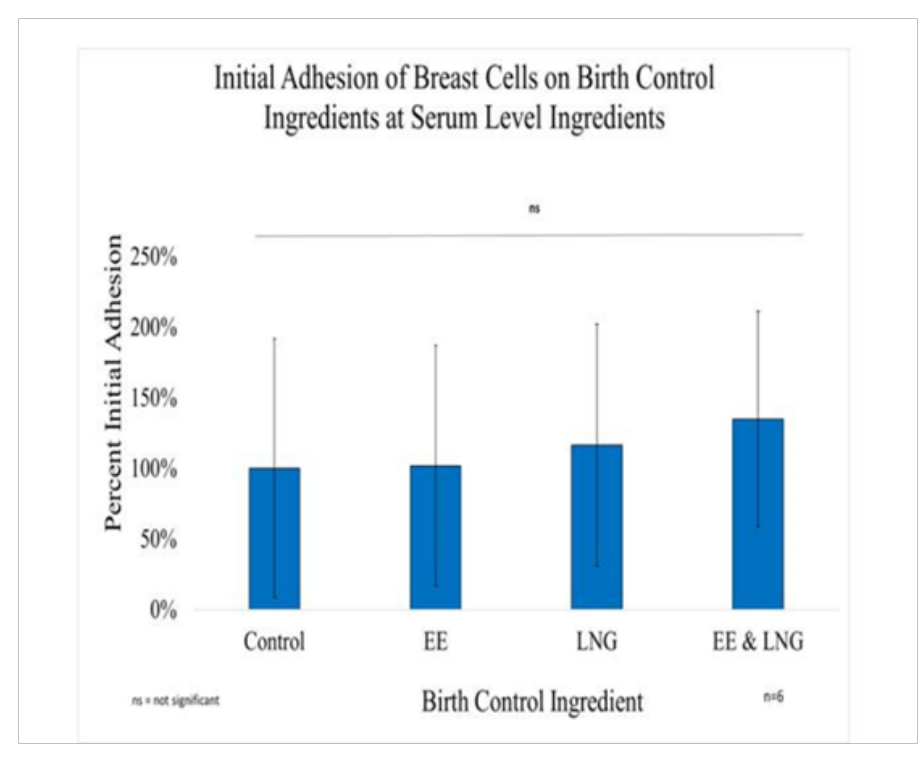

Figure 6 (A) Initial Adhesion of Breast Cells with Equivalent Blood Level Concentrations of Birth Control Ingredients on $10 \mu \mathrm{g} / \mathrm{ml}$ Collagen Matrices:Initial adhesion of breast cells did not have a significant impact with the addition of birth control ingredients whether they were added individually or as a mixture, an slight increasing adhesion rate trend was observed with the introduction of the ingredients.

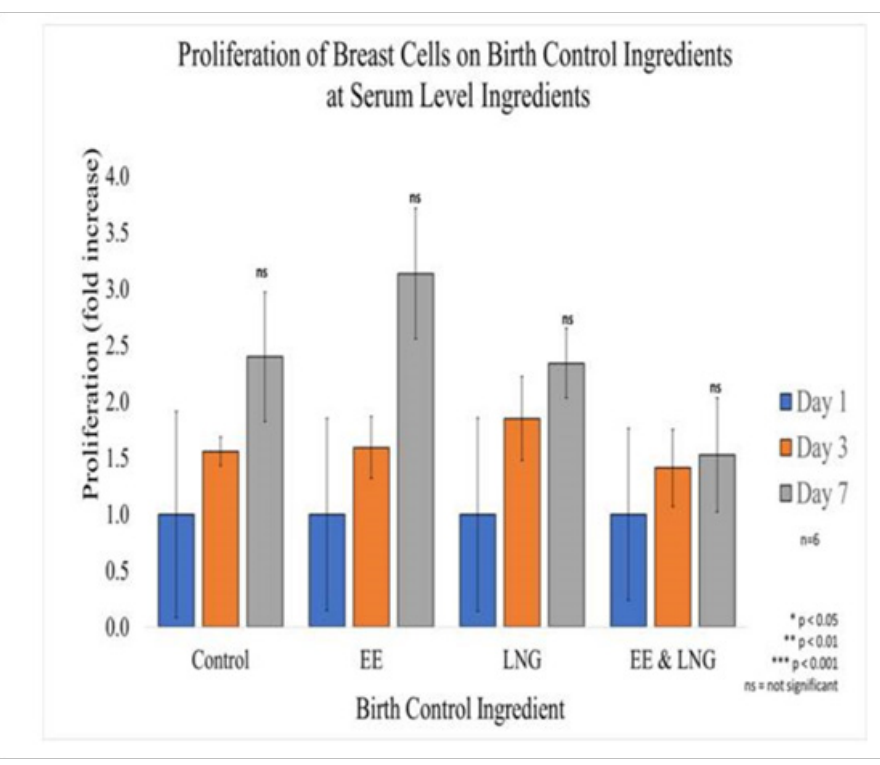

Figure 6 (B) Proliferation of Breast Cells with Equivalent Blood Level Concentrations of Birth Control Ingredients on $10 \mu \mathrm{g} / \mathrm{ml}$ Collagen Matrices:Proliferation of breast cells decreased with the addition of Levonorgestrel and Ethinyl Estradiol combined, it increased with the addition of Ethinyl Estradiol when added individually, no statistical significance was observed on Day 7.

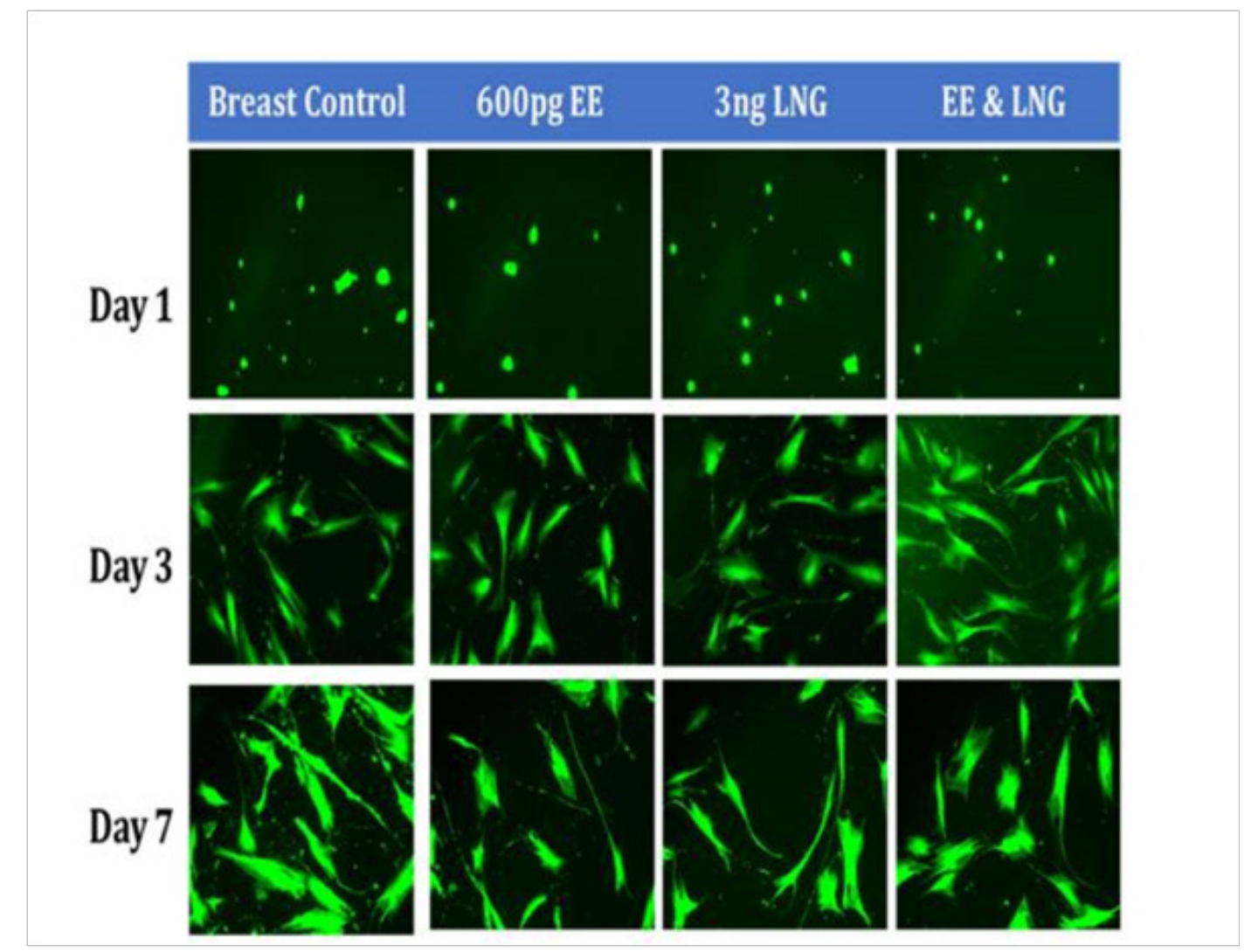

Figure 6 (C) Initial Adhesion and Proliferation of Breast Cells with Equivalent Blood Level Concentrations of Birth Control Ingredients on I0 $\mathrm{\mu g} / \mathrm{ml}$ Collagen Matrices:The cells appeared round after I hour incubation and consistently elongated as they proliferated. Cell morphology was not visibly altered when exposed to birth control ingredients at equivalent blood level concentrations, whether individually or in combination. However, a few breast cells were slightly more polygonal when exposed to EE alone and in combination of LNG by Day 7. 


\section{P-Values}

Figure 6 (D) P-Values of Breast Cells with Equivalent Blood Level Concentrations of Birth Control Ingredients on I0 4 g/ml Collagen Matrices. Value table indicating significance of experiment results.

Effect of levonorgestrel and ethinyl estradiol at equivalent blood level concentrations in ovarian cell adhesion and proliferation in 2D culture

In general, it was observed Ovarian cells have a slight decrease in initial adhesion when treated with birth control ingredients at serum level concentrations; $17 \%$ for Ethinyl Estradiol, 23\% for Levonorgestrel, and $31 \%$ when both ingredients were combined. However, there was no statistical significance in the results. The proliferation of ovarian cells in the presence of Levonorgestrel 3.04 $\mathrm{ng} / \mathrm{mL}$ and Ethinyl Estradiol $600 \mathrm{pg} / \mathrm{mL}$ trended higher than cells that were not treated. Although there was no statistical significance between the control and each condition by Day 7, the following was observed: $35 \%$ increase in proliferation when the cells are treated with $600 \mathrm{pg}$ of Ethinyl Estradiol, $40 \%$ increase in proliferation when treated with Levonorgestrel $3.04 \mathrm{ng} / \mathrm{ml}$, an $56 \%$ increase of proliferation when treated with both Levonorgestrel $3.04 \mathrm{ng} / \mathrm{mL}$ and Ethinyl Estradiol $600 \mathrm{pg} / \mathrm{mL}$. Nonetheless, the statistical significance of $p<0.001$ was observed between the control and each condition from Day 0 to Day 3 and Day 0 to Day 7, but not between Day 3 and Day 7 except for the comparison between EE and the combination (LNG \& $\mathrm{EE}$ ); the experiment was repeated $\mathrm{n}=6$ times.

\section{Breast cells}

\section{The effect of collagen and fibronectin matrix on breast cells}

Various concentrations of collagen and fibronectin matrixes were examined to determine the best substrate for initial cell adhesion and proliferation. In general, $5 \mu \mathrm{g} / \mathrm{mL}$ fibronectin substrate was observed to be the best for rapid breast cell adhesion, increasing the fibronectin concentration on $10 \mu \mathrm{g} / \mathrm{mL}$ did not seem to have an impact. Collagen concentration did not seem to have an impact on the adhesion of breast cells either. Overall, cell proliferation was higher in collagen than in fibronectin by Day 3, however, both conditions had a decline in proliferation by Day 7, which was later correlated to the health of breast cells. The $10 \mu \mathrm{g} / \mathrm{mL}$ Collagen substrate was identified as the preferred matrix for all proliferation assays.

\section{Breast cell adhesion and proliferation in 2D culture}

Initial adhesion and proliferation assays of breast cells were limited to 5,000 cells due to limitations on the number of cells available.

Effect of high concentrations ethinyl estradiol in breast cell adhesion and proliferation in 2D culture

Initial adhesion of breast cells did not have a significant impact on the addition of Ethinyl Estradiol. The proliferation of breast cells in decreased dramatically with the addition of EE, cells containing $20 \mu \mathrm{g} /$ $\mathrm{ml}$ EE decreased by $54 \%$ but did not display a statistical significance, $40 \mu \mathrm{g} / \mathrm{ml}$ of EE decreased by $86 \%$, and $80 \mu \mathrm{g} / \mathrm{ml}$ EE decreased by $93 \%$ when compared to the control. Higher concentrations $(40 \mu \mathrm{g} / \mathrm{ml}$ and $80 \mu \mathrm{g} / \mathrm{ml}$ ) of EE were statistically significant. The morphology of the cells was slightly altered by Day 3 , the cells started to lose their connectivity and appeared to have random shapes. By day 7 , it was clear that the cells treated with ethinyl estradiol had completely lost adhesion to neighboring cells.

\section{Effect of high concentrations levonorgestrel in breast cell adhesion} and proliferation in $2 \mathrm{D}$ culture

In general, the initial adhesion of breast cells did not have a significant impact with the addition of levonorgestrel; however, the proliferation of breast cells did show a statistical significance of at least $\mathrm{p}<0.01$ for the two higher concentrations. Overall, the greatest reduction in proliferation on Day 7 when compared to the control was observed at $47 \%$ for $0.05 \mathrm{mg} / \mathrm{ml} \mathrm{LNG}$, followed by $23 \%$ reduction for $0.025 \mathrm{mg} / \mathrm{ml} \mathrm{LNG}$, and $18 \%$ reduction for $0.0125 \mathrm{mg} / \mathrm{ml} \mathrm{LNG}$. The morphology of the breast cells was slightly altered by Day 3 , the cells started to look less elongated and appeared smaller at $0.025 \mathrm{mg} /$ $\mathrm{ml}$ LNG. By day 7, the cells treated with Levonorgestrel at the highest concentration of $0.05 \mathrm{mg} / \mathrm{ml}$ had completely lost adhesion to neighboring cells and morphed into a distorted shape. 
Effect of levonorgestrel and ethinyl estradiol at equivalent blood level concentrations in breast cell adhesion and proliferation in 2D culture

In general, it was observed Breast cells have a slight increase in initial adhesion when treated with birth control ingredients at serum level concentrations; $2 \%$ for Ethinyl Estradiol, $16 \%$ for Levonorgestrel, and $35 \%$ when both ingredients were combined. However, there was no statistical significance in the results. The proliferation of breast cells in the presence of Ethinyl Estradiol $600 \mathrm{pg} / \mathrm{mL}$ trended higher than cells that were not treated, whereas with Levonorgestrel 3.04ng/ $\mathrm{mL}$ and when combining both ingredients trended lower than cells that were not treated. Although there was no statistical significance between the control and each condition by Day 7, the following was observed: $29 \%$ increase in proliferation when the cells are treated with $600 \mathrm{pg}$ of Ethinyl Estradiol, 4\% decrease in proliferation when treated with Levonorgestrel $3.04 \mathrm{ng} / \mathrm{ml}$, an $37.5 \%$ decrease of proliferation when treated with both Levonorgestrel $3.04 \mathrm{ng} / \mathrm{mL}$ and Ethinyl Estradiol $600 \mathrm{pg} / \mathrm{mL}$. Nonetheless, the statistical significance of $\mathrm{p}<0.05$ was observed between Day 0 to Day 7 when comparing Control and EE, Control and LNG, EE and EE, EE and LNG, the Combination and LNG. The statistical significance of $p<0.05$ was also observed from Day 3 to Day 7 between the control and LNG and between $\mathrm{EE}$ and LNG; the experiment was repeated $\mathrm{n}=6$ times.

\section{Discussion}

The proliferation of animal cells is highly dependent on their environment, specifically on adhesion to the extracellular matrix (ECM), cell-cell adhesion and soluble factors. ${ }^{5}$ The most crucial influences are soluble growth factors and integrin-mediated adhesion, since the loss of adhesion usually results in cell cycle arrest, leading to apoptosis. ${ }^{5}$

\section{Ovarian cells}

Effect of high concentrations of ethinyl estradiol in ovarian cell adhesion and proliferation in 2D culture. Initial adhesion of ovarian cells did not have a significant impact on the addition of Ethinyl Estradiol, no apparent trend was observed as the concentration of EE was increased. The proliferation of ovarian cells decreased dramatically with the addition of Ethinyl Estradiol, a statistical significance of at least $p<0.01$ was observed on Day 7 . The cells appeared round after 1-hour incubation, slightly spindle as they proliferated. Cell morphology was altered from spindle to circular when exposed to Ethinyl Estradiol. Ovarian cells were noticeably larger and had lost adhesion to neighboring cells when exposed to EE.

Effect of high concentrations levonorgestrel in ovarian cell adhesion and proliferation in $2 \mathrm{~d}$ culture

Initial adhesion of ovarian cells did not have a significant impact on the addition of Levonorgestrel, an increased adhesion rate trend was observed as the concentration of LNG was increased. The proliferation of ovarian cells decreased with the addition of LNG, no statistical significance was observed on Day 7. The cells appeared round after 1-hour incubation, slightly spindle as they proliferated. Cell morphology was altered and became slightly more elongated when exposed to the highest concentration of Levonorgestrel. Ovarian cells were noticeably larger and started to lack adhesion to their neighboring cells when exposed to the highest concentration of LNG by Day 7. Our results are consistent with Yu et al., ${ }^{28}$ who found that progesterone inhibits proliferation on human ovarian cancerous cells by apoptosis via the up-regulation of $\mathrm{p} 53$ expression. ${ }^{28}$

Effect of levonorgestrel and ethinyl estradiol at equivalent blood level concentrations in ovarian cell adhesion and proliferation in 2D culture. Initial adhesion of ovarian cells did not have a significant impact with the addition of birth control ingredients whether they were added individually or as a mixture, a decreasing adhesion rate trend was observed with the introduction of the ingredients. The proliferation of ovarian cells increased with the addition of birth control ingredients whether they were added individually or as a mixture, no statistical significance was observed on Day 7. The cells appeared round after 1-hour incubation, slightly spindle as they proliferated. Cell morphology was not visibly altered when exposed to equivalent blood level concentrations of birth control ingredients whether individually or in combination. A few ovarian cells were visibly largeron Day 3, when exposed individually to EE and LNG. Most cells appeared to have a polygonal shape by Day 3 when exposed to a combination of EE and LNG. Our results are consistent with Fauvet et al. ${ }^{32}$

\section{Breast cells}

Effect of high concentrations ethinyl estradiol in breast cell adhesion and proliferation in 2D culture

Initial adhesion of breast cells did not have a significant impact with the addition of Ethinyl Estradiol, adhesion rate was similar to the control at $80 \mu \mathrm{g} / \mathrm{ml}$ but increased at $20 \mu \mathrm{g} / \mathrm{ml}$ and $40 \mu \mathrm{g} / \mathrm{ml}$. The proliferation of breast cells decreased dramatically with the addition of Ethinyl Estradiol, a statistical significance of at $p<0.001$ was observed on Day 7 at the highest concentrations. The cells appeared round after 1-hour incubation and consistently elongated as they proliferated. Cell morphology was altered from elongated to spindle-like when exposed to Ethinyl Estradiol. Breast cells were noticeably smaller in size and polygonal in shape, the loss of adhesion to neighboring cells was evident when exposed to EE. Our results are consistent with the use of high-dose estrogens in the treatment of advanced breast cancer. ${ }^{31}$

\section{Effect of high concentrations levonorgestrel in breast cell adhesion} and proliferation in $2 \mathrm{D}$ culture

Initial adhesion of breast cells did not have a significant impact on the addition of Levonorgestrel, a slight decrease in the adhesion rate at the highest concentration of LNG was observed. The proliferation of breast cells decreased with the addition of Levonorgestrel, a statistical significance of at least $\mathrm{p}<0.01$ for the highest concentrations was observed on Day 7. elongated as they proliferated. Cell morphology was slightly altered to a polygonal shape when exposed to Levonorgestrel, a loss of adhesion to neighboring cells was prominent at the highest concentration of LNG. Lanari et al., ${ }^{30}$ reported a decrease in proliferation when treating breast cancer cells with another popular progestin, medroxyprogesterone acetate (MPA) used in a contraceptive delivered intramuscularly. ${ }^{30}$

Effect of levonorgestrel and ethinyl estradiol at equivalent blood level concentrations in breast cell adhesion and proliferation in 2D culture

Initial adhesion of breast cells did not have a significant impact with the addition of birth control ingredients whether they were added individually or as a mixture, a slight increasing adhesion rate trend was observed with the introduction of the ingredients. The proliferation of 
breast cells decreased with the addition of Levonorgestrel and Ethinyl Estradiol combined, it increased with the addition of Ethinyl Estradiol when added individually, no statistical significance was observed on Day 7. The cells appeared round after 1-hour incubation and consistently elongated as they proliferated. Cell morphology was not visibly altered when exposed to birth control ingredients at equivalent blood level concentrations, whether individually or in combination. However, a few breast cells were slightly more polygonal when exposed to EE alone and in a combination with LNG by Day 7 . The increase in proliferation observed in cells treated with EE is compatible with Williams et al., ${ }^{15}$ who related the proliferative period on breast cells to the potency of oestrogen rather than progesterone in oral contraceptives. Cavailles et al., ${ }^{29}$ also reported increased proliferation in breast cells when treated with EE continuously at low concentrations and when using the pulse method to treat the cells at high concentrations for 1 hour.The decrease of proliferation in cells treated with LNG is consistent with Lanari et al. ${ }^{30}$ as his study found a similar impact by other progestins.

\section{Sources of error}

The addition of Norgestrel proved challenging as the solution of cells precipitated upon the addition of norgestrel and the experiment lacked homogeneity. Additionally, the PBS wash and inversion method during calcein processing varied in the volume of wash added. Pictures seemed to have been taken at a different magnification. Trypsinization protocol had to be doubled, as the breast cells did not completely detach in the first 7 minutes. However, depending on the person processing the plate, the interpretation of detachment was different.

\section{Conclusion}

Our initial work suggests that there could be a link between oral contraceptives and breast cancers in female users. The increased proliferation with Ethinyl Estradiol at equivalent blood level ingredients provides an opportunity for mutated cells to continue to grow which is the basis for cancer. On the other hand, the toxicity at high levels of EE links its impact to mutations that could potentially cause apoptosis. Although the experiments were run at extremes opposites, the literature confirms that the accumulation of both hormones in blood plasma has been demonstrated. Further studies are required to confirm our hypothesis; however, we can conclude that Ethinyl Estradiol introduced in the female body as contraceptive disrupts the behavior of both breast and ovarian cells similarly. Similarly, it can be concluded that Levonorgestrel disrupts the normal behavior of breast and ovarian cells, but further studies are required as we did not obtain statistical significance, which has been linked, to our sources of error.

\section{Future work}

In the pursuit of the hypothesis that Levonorgestrel and Ethinyl Estradiol in contraceptives could have an oncogenic effect in breast and ovarian cells, it is recommended to evaluate the impact of Ethinyl Estradiol on integrins as a loss of adhesion was observed followed by apoptosis. Furthermore, it is recommended to evaluate the process by which Levonorgestrel and Ethinyl Estradiol impact cell migration in each cell line.

\section{Acknowledgements}

The Authors would like to thank the Melissa McCoy for supporting the group through the experiments and encouraging the research.

\section{Conflicts of interest}

Authors declare that there is no conflict of interest.

\section{Funding}

California State University Channel Islands: Extended University. Department of Biotechnology, Biomedical Engineering Emphasis. One University Drive, Camarillo, California 93012.

\section{References}

1. Breast Anatomy: The National Breast Cancer. 2019.

2. Overview of the Breast - Breast Cancer. Johns Hopkins Pathology. 2019.

3. Di Cera E, Dang Q, Ayala Y. Molecular mechanisms of thrombin function. Cellular and Molecular Life Sciences (CMLS). 1997;53(9):701-730.

4. Green J, yamada K. Three-dimensional microenvironments modulate fibroblast signaling responses. Advanced Drug Delivery Reviews. 2007;59(13):1293-1298.

5. Schwartz M, Assoian R. Integrins and cell proliferation: regulation of cyclin-dependent kinases via cytoplasmic signaling pathways. Journal of Cell Science. 2018.

6. Lin F, Ren X, Doris G, et al. Three-Dimensional Migration of Human Adult Dermal Fibroblasts from Collagen Lattices into Fibrin/ Fibronectin Gels Requires Syndecan-4 Proteoglycan. Journal of Investigative Dermatology. 2005;124(5):906-913.

7. Bott K, Upton Z, Schrobback K, et al. The effect of matrix characteristics on fibroblast proliferation in 3D gels. Biomaterials. 2010;31(32):8454-8464.

8. Weinhandl K. The increasing potential of Chinese hamster ovary cells 2019.

9. What Is Ovarian Cancer? 2019.

10. https://www.siumed.edu/

11. Hynes R. Integrins: Bidirectional, Allosteric Signaling Machines. Cell. 2002;110(6):673-687.

12. Huttenlocher A, Horwitz A. Integrins in Cell Migration. Cold Spring Harbor perspectives In Biology. 2011;3(9):a005074-a005074.

13. Lambert A, Ozturk S, Thiagalingam S. Integrin Signaling in Mammary Epithelial Cells and Breast Cancer. ISRN Oncology. 2012;1-9.

14. Mayo Clinic. Ovarian cancer - Symptoms and causes. 2019.

15. Williams G, Anderson E, Howell A, et al. Oral contraceptive (OCP) use increases proliferation and decreases oestrogen receptor content of epithelial cells in the normal human breast. International Journal of Cancer. 1991;48(2):206-210.

16. Vessey M, Baron J, Doll R, et al. Oral contraceptives and breast cancer: Final report of an epidemiological study. British Journal of Cancer. 1983;47(4):455-462. 
17. Brinton L, Brogan D, Coates R, et al. Breast Cancer Risk Among Women Under 55 Years of Age by Joint Effects of Usage of Oral Contraceptives and Hormone Replacement Therapy. Menopause. 1998;3(5):145-151

18. Pandey G, Sharma M, Pandey S. Experimental hepatotoxicity produced by ethinyl estradiol. Toxicology International. 2011;18(2):160.

19. Understanding your menstrual cycle fact sheet. Women's Health Queensland Inc. 2019.

20. Holly Ernst P. Long-term effects of birth control: Is it safe to use indefinitely? Medical News Today. 2019

21. National Research Council (US) Committee on Population Contraception and Reproduction: Health Consequences for Women and Children in the Developing World. Washington (DC): National Academies Press (US); 1989.

22. Murphy $\mathrm{N}, \mathrm{Xu} \mathrm{L}$, Zervoudakis $\mathrm{A}$, et al. Reproductive and menstrual factors and colorectal cancer incidence in the Women's Health Initiative Observational Study. British Journal of Cancer. 2017;116(1):117-125.

23. Siddiqui I, Sanna V, Ahmad N, et al. Resveratrol nanoformulation for cancer prevention and therapy. Annals of The New York Academy of Sciences. 2015;1348(1):20-31.

24. Ovarian cancer - Symptoms and causes. 2019.

25. USCS Data Visualizations. 2019.

26. Devineni D, Skee D, Vaccaro N, et al. Pharmacokinetics and Pharmacodynamics of a Transdermal Contraceptive Patch and an Oral Contraceptive. The Journal of Clinical Pharmacology. 2007;47(4):497-509.

27. Archer D, Stanczyk F, Rubin A, et al. Ethinyl estradiol and levonorgestrel pharmacokinetics with a low-dose transdermal contraceptive delivery system, AG200-15: a randomized controlled trial. Contraception. 2012;85(6):595-601.
28. Yu S, Lee M, Shin S, et al. Apoptosis induced by progesterone in human ovarian cancer cell line SNU-840. Journal of Cellular Biochemistry. 2001;82(3):445-451.

29. Cavailles V, Gompel A, Portois M, et al. Comparative activity of pulsed or continuous estradiol exposure on gene expression and proliferation of normal and tumoral human breast cells. Journal of Molecular Endocrinology. 2002;65-175.

30. Lanari C, Molinolo A. Progesterone receptors - animal models and cell signaling in breast cancer Diverse activation pathways for the progesterone receptor - possible implications for breast biology and cancer. Breast Cancer Research. 2002;4(6).

31. Coelingh Bennink H, Verhoeven C, Dutman A, et al. The use of high-dose estrogens for the treatment of breast cancer. Maturitas. 2017;95:11-23

32. Fauvet R, Etienne C, Poncelet C, et al. Effects of progesterone and anti-progestin (mifepristone) treatment on proliferation and apoptosis of the human ovarian cancer cell line, OVCAR-3. Oncology Reports. 2006 .

33. Catherino W, Jeng M, Jordan V. Norgestrel and gestodene stimulate breast cancer cell growth through an oestrogen receptor mediated mechanism. British Journal of Cancer. 1993;67(5):945-952.

34. Hilakivi-Clarke L, de Assis S, Warri A. Exposures to Synthetic Estrogens at Different Times During the Life, and Their Effect on Breast Cancer Risk. Journal of Mammary Gland Biology and Neoplasia. 2013;18(1):25-42.

35. Marchbanks PA, Curtis KM, Mandel MG, et al. Oral contraceptive formulation and risk of breast cancer. Contraception. 2012;85:342350 .

36. Collaborative Group on Hormonal Factors in Breast Cancer. Breas cancer and hormonal contraceptives: collaborative reanalysis of individual data on 53,297 women with breast cancer and 100,239 women without breast cancer from 54 epidemiological studies. Lancet. 1996;347(9017):1713-1727. 